\title{
Association of Commonwealth Literature and Language Studies
}

Following the first Conference on Commonwealth Literature, representatives of English Departments from universities in the Commonwealth met at Sadler Hall, University of Leeds, in September 1969, to establish an Association for Commonwealth Literature and Language Studies. Professor A. Norman Jeffares was appointed Chairman of the provisional Committee which is preparing for a further Conference on Commonwealth Literature and for the first General Meeting of the Association. The first number of The Journal of Commonwealth Literature was published in September 1969, by Heinemann Educational Books Ltd. and the University of Leeds. It will appear again in September 1966 and thereafter twice yearly in March and September. Its aim is to provide information about creative writing in English from all Commonwealth countries, excluding Great Britain.

\section{University of Cambridge: Centre of African Studies}

A bibLIographical centre for African studies in Cambridge has been in existence for four years as part of a Centre for Afro-Asian Studies set up in May I96x in the building of the Faculty of Economics and Political Science, under the direction of Mr. Kenneth Berrill. The Librarian, Miss Julia Allen, has prepared a catalogue of over 39,000 cards of books, theses, government documents, mimeographed material, and articles from approximately 600 periodicals, and supplies an index of current publications on Africa. Seminars and lectures have also been held at the Centre.

On 13 May 1964 the University established a Centre of South Asian Studies and it was decided in July 1965 that the existing Afro-Asian Centre should become a Centre of African Studies. Dr. A. I. Richards will act as Director of the Centre, with the advice of a Committee of Management consisting of representatives of the Faculties of Economics and Political Science, History, Law, Geography and Geology, Agriculture, and Archaeology and Anthropology.

The bibliographical activities of the Centre will be continued although papers dealing with Asia have been handed to the new South Asian Centre. Post-graduate seminars have been planned on 'African peasant economics', 'Decision-making by traditional African councils', and 'Education and social structure in developing countries'. General lectures on the problems of African development will be continued. It is hoped to organize an interdisciplinary research project on African agricultural enterprise in East Africa and the emergence of commercial farming from traditional subsistence cultivation. This project will be organized by the Centre in co-operation with the School of Agriculture of the University. The work will be conducted in at least two comparative areas, of which the first will be Uganda.

\section{Une Documentation Cartographique sur l'Afrique au Sud du Sahara}

Dans le cadre des activités du Centre d'Études Africaines de l'École Pratique des Hautes Études, un groupe de chercheurs s'attache, depuis dix-huit mois environ, sous la direction de G. Sautter, à constituer une collection de documents cartographiques sur l'Afrique au sud du Sahara.

Les documents recherchés sont de deux types: les cartes annexées à un ouvrage ou un article, et les cartes publiées en tant que telles (accompagnées le plus souvent d'une notice). La collection se veut la plus complète possible, et ne rejette aucun thème scientifique.

\footnotetext{
I See Africa, xxxii, January 1962, p. 71.
} 